\title{
Rare Events and Annuity Market Participation*
}

\author{
Paula Lopes ${ }^{\dagger}$ \\ London School of Economics and FMG \\ and \\ Alexander Michaelides ${ }^{\ddagger}$ \\ London School of Economics, CEPR and FMG
}

November 2005

\footnotetext{
${ }^{*}$ We thank Edmund Cannon, Frank de Jong and conference participants at the 6th RTN conference at LSE for helpful comments and suggestions.

${ }^{\dagger}$ Address: Financial Markets Group, London School of Economics, Houghton Street, London, WC2A 2AE, United Kingdom. Email: P.Lopes@lse.ac.uk.

${ }^{\ddagger}$ Address: Department of Economics, London School of Economics, Houghton Street, London, WC2A 2AE, United Kingdom. Email: A.Michaelides@lse.ac.uk.
} 


\begin{abstract}
We investigate whether a rare event (like the default of the annuity provider) can explain the annuity market participation puzzle. High risk aversion is needed to change behavior in the presence of such a disastrous shock but higher risk aversion also makes annuities more valuable. Therefore, these rare events are unlikely candidates to explain the low take-up of voluntary annuities.
\end{abstract}

JEL Classification: E21, H00.

Key Words: Annuity Provision, saving during retirement, rare events.

\title{
1 Introduction
}

Why are annuities not voluntarily taken up by a larger number of retirees? In the individual consumption/savings-portfolio choice literature, a very important participation puzzle arises from the revealed preference of households not to voluntarily buy annuities at retirement, despite the strong theoretical reasons that point towards a strong demand for these products. Specifically, as early as 1965, Yaari demonstrated that risk aversion would be sufficient to induce a household to buy an actuarily fair annuity as protection against life expectancy risk. Yet, despite this early strong theoretical result, voluntary annuity demand remains very low in the data ${ }^{1}$, what is known as the "annuity market participation puzzle" 2 .

We investigate the merits of an explanation that is based on the idea that the household perceives that there is a small probability that the annuity provider will default. The mo-

\footnotetext{
${ }^{1}$ More recently, Davidoff, Brown and Diamond (forthcoming) show that complete annuitization is optimal in a more general setting than Yaari (1965) when markets are complete.

${ }^{2}$ Mitchell, Poterba, Warshawsky and Brown (1999) find that annuities in the U.S. are not actuarily fair, while a similar argument is made by Finkelstein and Poterba (2002, 2004) for U.K. data where self selection in the annuity market is reflected in the price of the annuity. Nevertheless, Mitchell et. al. (1999) argue that annuity pricing is not sufficient to explain the low take-up and argue that the "money's worth of individual annuities" is actually quite good. Friedman and Warshawsky (1990) emphasize the importance of a bequest motive, and Davidoff, Brown and Diamond (forthcoming) consider habit formation. Another set of explanations changes the economic environment. Bernheim (1991) and Brown et. al. (2001), for instance, note that social security could act as a sufficient level of annuity provision.
} 
tivation comes from the observation that the operation of the annuity market involves the purchaser handing a large lump sum to the provider up front, in exchange for the annuity payments from then on, without any access to the initial sum thereafter. Nevertheless, if the household does not have any other savings to fall back on, then the small probability of a disastrous event can potentially eliminate annuity demand, since the marginal utility of consumption as consumption approaches zero is infinite ${ }^{3}$. Moreover, recent experience with large public companies defaulting (Enron in the U.S. and more relevant for this application, Equitable Life in the U.K.) implies that households might be concerned with the promises offered to them by annuity providers. Finally, in a recent survey of annuity owners by the American Council of Life Insurers (2003) "the stability of the insurance company was the most influential factor (81\%) in deciding which annuity to buy" (p.9).

We quantitatively evaluate the importance of this mechanism in affecting annuity demand in the presence of other realistic features of the consumer's objectives during retirement. Our findings suggest that a small perceived probability of default cannot explain the annuity market participation puzzle. For a small-probability disastrous event to affect behavior, risk aversion needs to be high. But for high risk aversion, annuities are more valuable in insuring mortality risk. As a result, the net effect from our quantitative calculations implies that a rare event is unlikely to be the main explanation of the annuity market participation puzzle.

The remainder of the paper is organized as follows. In Section 2, we present the model, solution technique and parameterization. In Section 3, the results are discussed and section 4 concludes.

\footnotetext{
${ }^{3}$ A similar approach is taken by Carroll (1997) who shows that a small probability of a disastrous transitory labor income shock can generate no borrowing, even if households would otherwise want to borrow. In the same spirit, Rietz (1988) argues that a small probability of a disastrous consumption shock could explain the equity premium puzzle.
} 


\section{The Model}

\subsection{Preferences}

We model household consumption/saving and annuity choices from retirement onwards. ${ }^{4}$ The household may either be an individual or a couple in which case the household only dies when both individuals die. The household lives for a maximum of $T$ periods. We let each period in the model correspond to one year, and we allow for uncertainty in the age of death in the manner of Hubbard, Skinner and Zeldes (1995). Let $p_{t}$ denote the probability that the household is alive at date $t$, conditional on being alive at date $t-1\left(p_{1} \equiv 1\right)$. Household preferences are then described by the time-separable power utility function:

$$
E_{1} \sum_{t=1}^{T} \beta^{t-1}\left(\prod_{j=1}^{t-1} p_{j}\right)\left[p_{t} \frac{C_{t}^{1-\gamma}}{1-\gamma}+\left(1-p_{t}\right) B \frac{W_{t}^{1-\gamma}}{1-\gamma}\right]
$$

where $\beta$ is the time discount factor and $\gamma$ is the coefficient of relative risk aversion. With probability $\left(1-p_{t}\right)$ the household dies and leaves wealth $W_{t}$ as a bequest. The parameter $B$ measures the intensity of the bequest motive. In each period $t, t=1, \ldots, T$, the household chooses optimal consumption $C_{t}$ subject to certain constraints that depend on the economic environment (the amount of annuities available). In the first period of retirement, the household also chooses the level of annuity to be purchased.

\subsection{Available real annuity contracts}

We study real annuity contracts ${ }^{5}$. One main component of the analysis involves calculating the expected present discounted value (EPDV) of the annuity, since the insurance company uses this value to calculate the price of the product. The EPDV will depend on the annual annuity payment, the survival probabilities and the term structure of interest rates at the time of retirement. For instance, if at retirement age the annualized real interest rate on a bond with maturity $t$ is $R_{t, 1}$, and the household purchases a real annuity that makes an

\footnotetext{
${ }^{4}$ The dynamic model is in the line of the precautionary savings literature models proposed by Deaton (1991) and Carroll (1997) but the current setup focusses only on decisions after retirement.

${ }^{5}$ The results continue to hold for nominal contracts but we omit them for brevity.
} 
annual payment of $A$, the expected present discounted value (EPDV) of the annuity payouts is given by:

$$
E P D V=\sum_{j=1}^{T} \frac{A \prod_{k=1}^{j} p_{k}}{\left(1+R_{j, 1}\right)^{j}}
$$

We use this EPDV to determine the cost of buying an annuity at retirement by multiplying the EPDV with one plus a load factor $(P)$ which is greater than or equal to zero, obtaining a measure of the "money's worth" of the annuity. If the load factor is zero, then the annuity contract is actuarially fair and the "money's worth" equals one ${ }^{6}$. Empirical evidence by Mitchell et. al. (1999) illustrates that the load factor varies between 8 and 20 percent depending on different assumptions about discounting and mortality tables; a 20 percent value is suggested as indicative of the transaction cost involved ${ }^{7}$.

We need to make an assumption on the discount rates applied to future annuity payments to determine the value of an annuity to an individual. We assume a flat yield curve in discounting annuity payouts but the results are robust to changing this assumption given the low observed volatility of real interest rates.

\subsection{Retirement Income}

At retirement age the household has financial wealth $X_{1}$, which can be used to purchase an annuity. In addition, the household is endowed with gross real pension income in each period, $L$. We use a lower case letter to denote the natural $\log$ of the variable, i.e., $l \equiv \log (L)$. Household $j$ 's real pension income $l_{j}$ is exogenous. Note that the presence of a state pension does crowd out the demand for annuities to a certain extent but this is realistic feature of

\footnotetext{
${ }^{6}$ The annuity premium/load factor $(P)$ and the money's worth are therefore defined as:
}

$$
\text { Annuity Cost }=(1+P) \times E P D V
$$

and

$$
\text { Money's Worth }=\frac{E P D V}{\text { AnnuityCost }} .
$$

\footnotetext{
${ }^{7}$ The difference between the EPDV and the premium cost of the annuity covers expenses and other administrative costs associated with the sales of annuities and normal profits of insurance companies.
} 
decision-making during retirement. We experiment with different pension levels later on in the paper because we do recognize the importance of this assumption on the demand for annuities.

In each period after retirement there is a probability $\theta$ that the insurance company defaults on its liabilities. In this event, the consumer will not receive any annuity payments thereafter.

\subsection{Summary of the household's optimization problem}

In summary, the household's control variables are $\left\{C_{t}\right\}_{t=1}^{T}$ and at the initial date whether to purchase an annuity and, if so, how much initial wealth to convert into the annuity. The

vector of state variables can be written as $S_{t}=\left\{t, X_{t}, A\right\}_{t=1}^{T}$ where $X_{t}$ is real liquid wealth or cash-on-hand and $A$ is the real annuity purchased at retirement.

The equation describing the evolution of real cash-on-hand can be written as:

$$
X_{t+1}=\left(X_{t}-C_{t}\right)\left(1+R_{1, t+1}\right)+L_{t+1}+A
$$

This equation assumes that savings are invested in one-period bonds. Uncertainty during retirement arises from the random probability of death and the probability that the annuity provider defaults on their obligations.

\subsection{Solution technique and Parameterization}

This problem cannot be solved analytically. Given the finite nature of the problem a solution exists and can be obtained by backward induction. We discretize the cash on hand state variable using a higher number of grid points at lower levels of cash on hand and solve the model in an annual frequency. We assume a constant real interest rate equal to $2 \%$ (the results are robust to using a mean-reverting process). Period one is taken to be age 65 , the most common retirement age. Conditional survival probabilities for the male population are taken from the US census from ages 65 to 99. To simplify, we assume that the individual dies by age 100 with certainty. In the baseline case we use a coefficient or relative risk aversion equal to 3 and a discount factor equal to 0.98 . The bequest parameter is set to zero. 
We choose the probability of default in a very conservative way to explore the range of outcomes that might be possible under different perceptions about this probability. Specifically, an annual probability of one (five) percent is equivalent to a BB (B) corporate debt rating by a credit rating agency like Moody's. The cumulative probability of default within 15 years is then calculated to be around 20\% (31\%) for a BB (B) company. We view these as very conservative upper bounds on the probability of default (especially considering the assumption that the payout to the annuitant in this state is assumed to be zero).

\subsection{Wealth Distribution and Pension Income}

We will compute aggregate demands for annuities after computing the optimal level of annuity to be purchased. To do that we need the wealth distribution and we use the observed wealth data for retirees from the 1998 Survey of Consumer Finances (SCF), which offers a detailed description of U.S. family balance sheets. In order to match the definition of wealth in our model to the one in the data we add two variables, namely: income (which represents households' gross income of the previous year) and financial wealth (which represents households' accumulated wealth in financial assets, excluding retirement and housing wealth). Also, we consider individuals aged between 55 and 70 because these are the ones aproaching retirement or just retired and therefore representative for the demand of annuities. Pension income is the median pension income received by retired individuals in the $1998 \mathrm{SCF}$.

\section{Results}

\subsection{Consumption and Wealth Profiles without Default}

Figure 1 graphs the consumption profiles for a median-wealth retiree for three cases in the absence of a default state. In the first one we exogenously assume that there is no access to the annuity market and optimal consumption is therefore decreasing during retirement given the assumptions about the survival probabilities, the discount and the interest rate. In the second case the consumer picks the optimal annuity level when the load factor is zero. The consumer optimally annuitizes all wealth and consumes a constant amount which equals the 
state pension and the annuity payout thereafter. In the third case, we assume a $20 \%$ load factor and there is incomplete annuitization: the consumption profile is decreasing for the first few periods in retirement and then stays flat at the pension and annuity payout.

The wealth profiles (omitted for brevity) reflect these consumption choices. In the constant consumption case, all wealth is spent on purchasing the annuity and wealth drops to zero after retirement. In the no annuity case, there is decumulation of wealth as consumption is higher than pension income during most of retirement and the $20 \%$ load factor case is an intermediate profile between these two extremes.

The results illustrate the annuity market participation puzzle since a median wealth household optimally annuitizes almost all financial wealth at retirement.

\subsection{Annuity Demands with Default}

We now report a series of comparative statics results to understand the optimal policy choices of a household in the presence of a positive probability of default. Figure 2 plots the annuity demand choices as a function of wealth at the time of retirement and the comparative statics are performed with respect to the probability of default. For low wealth levels the demand for annuities is zero, reflecting the implicit annuity in the form of the pension income received during retirement and, more importantly, the inability of a financiallypoor household to purchase an annuity (Lopes, 2003). Higher wealth levels generate a monotonically increasing demand for annuities, while the shape of the policy function is similar throughout the probabilities of default.

A higher default probability implies a higher level of weath for which annuity demand will become positive and, moreover, annuity demand is strictly lower for a given wealth level. The important question we address is whether the presence of such a perception on the part of households can have quantitatively large effects on annuity demand and therefore on the propensity to participate in the annuity market. The figure illustrates that the policy functions are affected by a very small amount, even in the presence of a sizeable probability of default at an annual level (5\%).

What explains the result that a small perceived probability of default cannot explain the 
annuity market participation puzzle? For a disastrous event to affect behavior, risk aversion needs to be high. But for high risk aversion, annuities are more valuable in insuring mortality risk. As a result, the net effect from our quantitative calculations implies that a rare event is unlikely to be the main explanation of the annuity market participation puzzle.

\subsection{Total Annuity Demand}

Given that we have computed policy functions for annuity demands as a function of financial wealth at retirement age and given the observed wealth distribution in the data, we can combine this information to calculate the total level of annuity demand implied by the model and the empirical distribution of financial wealth at retirement. Table 1 computes the change in annuity demand and participation rate in response to changes in the probabilities of default, for different levels of risk aversion and pension income. The results illustrate that relative to the no-default case, the participation rate in the population is reduced by very small amounts even for the high (upper bound) probabilities of default that we are assuming. Moreover, the total amount of annuities purchased is also reduced by very small amounts reflecting the results from the policy functions. Table 1 corroborates that annuity demand hardly changes even in the presence of disastrous events that might occur with a relatively high probability.

\section{Conclusion}

We have argued that a small probability of default of an annuity provider (a rare event) should not reduce the demand for annuities of households with empirically reasonable levels

of risk aversion and wealth levels at retirement. Further work is needed to better understand what are reasonable models of behavior that can explain limited participation in annuity markets.

\section{References}

American Council of Life Insurers, April 2003, "Profile of Immediate Annuity Owners." 
Bernheim, B.Douglas, 1991, "How Strong are Bequest Motives? Evidence Based on Estimates of Demand for Life Insurance and Annuities", Journal of Political Economy, 99 (5), 899-927.

Brown, Jeffrey R., Olivia S.Mitchell, and James M. Poterba, 2001, "The Role of Real Annuities and Indexed Bonds in an Individual Accounts Retirement Program," in Risk Aspects of Investment-Based Social Security Reform, ed. John Y. Campbell and Martin Feldstein.

Campbell, John Y. and João F. Cocco, 2003, "Household Risk Management and Optimal Mortgage Choice", The Quarterly Journal of Economics 118: 1449-1494.

Campbell, John Y., Andrew W. Lo, and A. Craig MacKinlay, 1997, The Econometrics of Financial Markets, Princeton University Press, Princeton, NJ.

Carroll, Christopher D., 1997, "Buffer-Stock Saving and the Life-Cycle/Permanent Income Hypothesis", Quarterly Journal of Economics 114, 433-495.

Davidoff, Thomas, Jeffrey Brown and Peter Diamond. "Annuities and Individual Welfare" American Economic Review, forthcoming.

Deaton, Angus. 1991. "Saving and Liquidity Constraints." Econometrica 59(5): 1221-48.

Finkelstein, Amy and James Poterba, 2002, "Selection Effects in the United Kingdom Individual Annuities Market", The Economic Journal, 112, 28-42.

Finkelstein, Amy and James Poterba, 2004, "Adverse Selection in Insurance Markets: Policyholder Evidence from the U.K. Annuity Market", Journal of Political Economy, 112, 1 (1), pp. 183-208.

Friedman, B. and Mark Warshawsky, 1990, "The Cost of Annuities: Implications for Saving Behavior and Bequests, Quarterly Journal of Economics, 105, 135-154.

Hubbard, Glenn, Jonathan Skinner, and Stephen Zeldes. 1995. "Precautionary Saving and Social Insurance." Journal of Political Economy, 103: 360-399. 
Lopes, Paula. 2003. "Are Annuities Value for Money? Who Can Afford Them?" LSE FMG Discussion Paper 2003.

Mitchell, Olivia, James Poterba, Mark Warshawsky and Jeffrey Brown, 1999, "New Evidence on Money's Worth of Individual Annuities," American Economic Review, 89, 1299-1318.

Rietz, Thomas. 1988. "The Equity Risk Premium: A Solution." Journal of Monetary Economics, 22(1):117-31.

Yaari, Menahem, 1965, "Uncertainty Lifetime, Life Insurance and the Theory of the Consumer," Review of Economics Studies, 32, 137-150. 
Table 1: Average Annuity Demand and Participation

\begin{tabular}{lccc}
\hline & Baseline & Low Pension & Low Risk Aversion \\
\hline Probability & Demand & Demand & Demand \\
\hline of default & (Participation) & (Participation) & (Participation) \\
\hline $0 \%$ & $2.54(88.4)$ & $2.87(100.0)$ & $1.38(53.4)$ \\
$1 \%$ & $2.43(85.0)$ & $2.73(100.0)$ & $1.24(49.5)$ \\
$2 \%$ & $2.35(85.0)$ & $2.66(100.0)$ & $1.10(47.6)$ \\
$5 \%$ & $2.14(76.5)$ & $2.48(99.60)$ & $0.70(33.3)$ \\
\hline
\end{tabular}

Notes to Table 1: Demand reports the average annuity demand in thousands of U.S. dollars per annum, whereas participation reports the percentage of households that will participate in the annuity market. The low pension experiment decreases the real pension to 5000US\$ per annum and low risk aversion is the case with a relative risk aversion coefficient equal to 0.5. 
Figure 1: Consumption Profiles

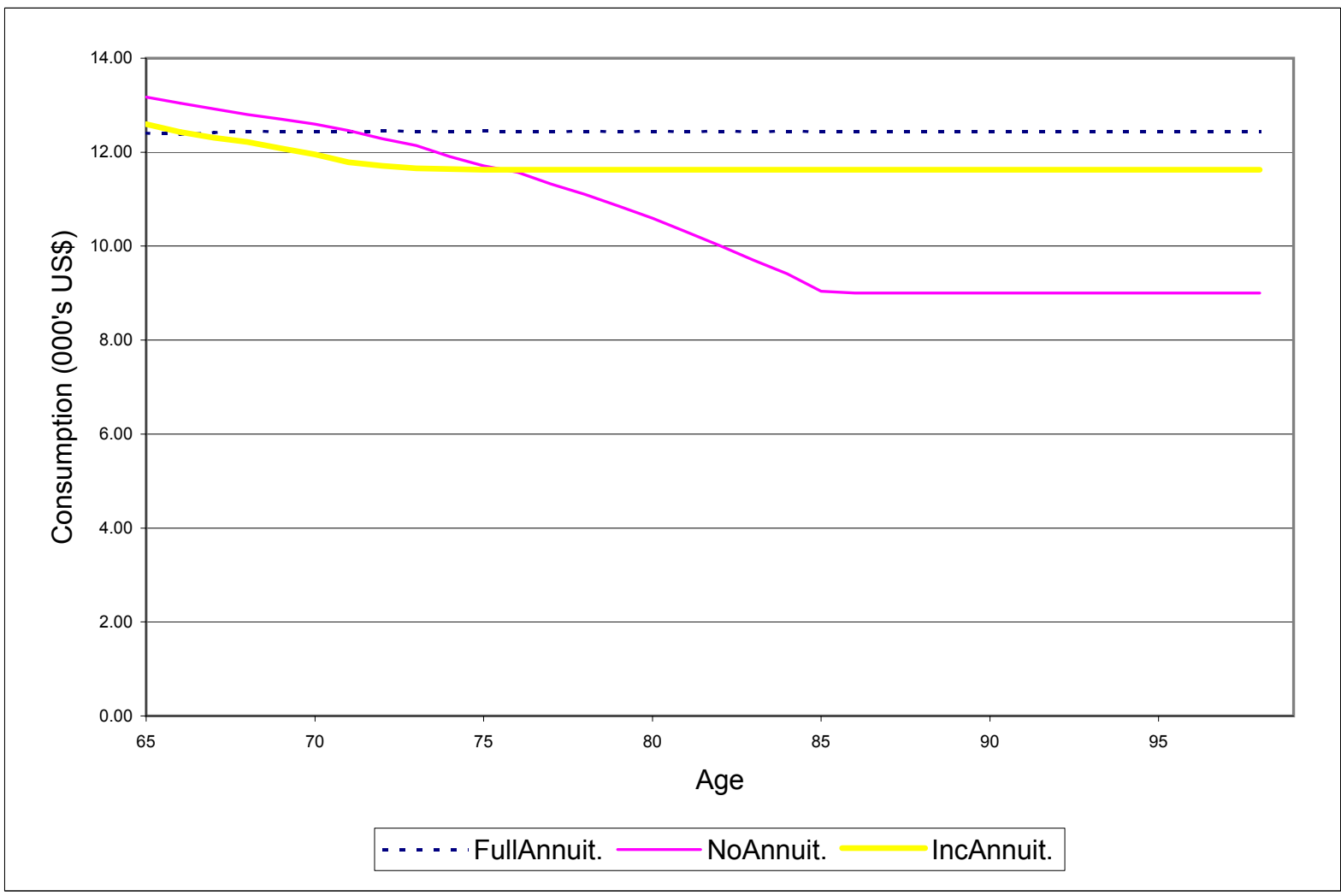

Note to Fig. 1: This figure plots the consumption profiles during retirement for median-wealth retiree for the case of no annuity access, complete annuitization and incomplete annuitization.

Figure 2: Annuity Demand as a Function of Wealth at Retirement

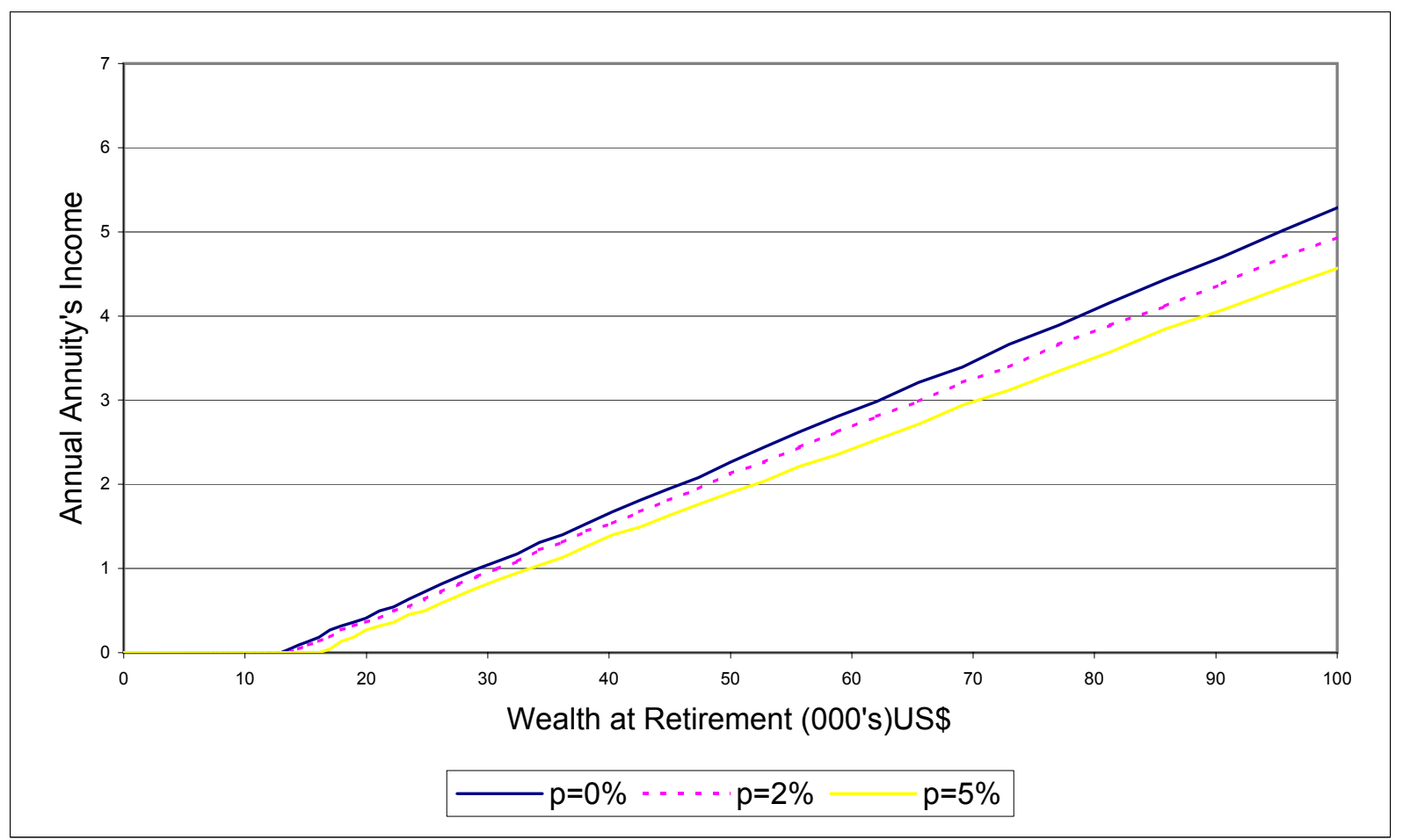

Note to Fig. 2: This graph plots annuity demand as a function of wealth at retirement for different levels of probability of default. 